\title{
Clarification of the taxonomic identity, typification and nomenclature of Impatiens benthamii (Balsaminaceae)
}

\author{
R. Gogoi ${ }^{1 *}$, B.B.T. Tham ${ }^{2}$, N. Sherpa ${ }^{1}$, J. Dihingia ${ }^{3} \&$ S. Borah ${ }^{4}$ \\ ${ }^{1}$ Botanical Survey of India, Sikkim Himalayan Regional Centre, \\ P.O. Rajbhawan, \\ Gangtok-737103, Sikkim, India \\ "rajibdzuko@gmail.com \\ ${ }^{2}$ Botanical Survey of India, Eastern Regional Centre, \\ Shillong - 793003, Meghalaya, India \\ ${ }^{3}$ Dakshin Kamrup Bidyapith High School, \\ Mirza - 781125, Assam, India \\ ${ }^{4}$ Department of Botany, Gauhati University, \\ Guwahati - 781014, Assam, India
}

\begin{abstract}
Impatiens benthamii Steenis (Balsaminaceae) is re-collected from the type locality, Khasi Hills, Meghalaya, India, almost 60 years since it was last collected. The history and nomenclatural complexity of this little-known endemic species is discussed. A clarification of the distributional range of the species is given due to previous erroneous reports. To facilitate its proper identification, a detailed description based on live materials and colour photographs is provided. The characters of Impatiens benthamii are compared to those of closely related species. A lectotype is designated.
\end{abstract}

Keywords. Distribution, endemic, Khasi Hills, lectotype

\section{Introduction}

The Indian species Impatiens radicans Benth. ex Hook.f \& Thomson first appeared in Wallich (1832) but this name was not validly published. It was later validly published in Hooker \& Thomson (1859). In the same publication they also published Impatiens salicifolia Hook.f. \& Thomson which was later synonymised with I. radicans (Hooker, 1905). However, the name Impatiens radicans Benth. ex Hook.f. \& Thomson is a later homonym of $I$. radicans Zoll. \& Moritzi (Moritzi, 1846). Impatiens radicans Zoll. $\&$ Moritzi is now treated as a synonym of I. cyclocoma Miq. Likewise, Impatiens salicifolia Hook.f. \& Thomson is a later homonym of I. salicifolia Turcz. (Turczaninow, 1859). Whilst studying the Impatiens species of Java, Van Steenis (1948) was the first to notice that the Indian species did not have a legitimate name and named it $I$. benthamii Steenis in honour of George Bentham.

Impatiens benthamii Steenis is a very little-known endemic species confined to the Khasi and Jaintia Hills in the Indian state of Meghalaya. In the Plants of the World Online portal (POWO, 2019), publications by Sarmah \& Borthakur (2009) 
and Mostaph \& Uddin (2013) are cited, the former based on material from Manas National Park in Assam from only $300 \mathrm{~m}$ altitude, as the basis for acceptance of this name. During our study the authors have critically examined the specimens cited by Sarmah \& Borthakur (2009) and found that they are not Impatiens benthamii but rather I. tripetala Roxb. (Joseph 45110 (ASSAM); Sarmah 292 (GUBT)), a commonly occurring low altitude species.

As Impatiens benthamii is a plant of higher altitudes above $1000 \mathrm{~m}$, being found in the Khasi Hills of present-day Meghalaya, the record of it from Bangladesh (Mostaph \& Uddin, 1913), based on specimens labelled as from Sylhet (or under different spellings of this place name), is mistaken because the old East India Company Herbarium specimens from higher altitudes labelled as Sylhet are actually from the Khasi Hills in India (Clarke, 1913; Watson, 2013).

Impatiens benthamii has only been collected in the Khasi \& Jaintia Hills of Meghalaya and has not been seen in other parts of the state such as the Garo Hills. Two of the authors (SB \& BBTT) separately collected this species from different localities in the Khasi Hills and sent the materials and photos for identification to RG \& NS as they are revising the genus in Himalaya. After critical study and perusal of the literature (Hooker \& Thomson, 1859; Hooker, 1875; Hooker, 1905; Vivekananthan et al., 1997; Gogoi et al., 2018) they identified the material as Impatiens benthamii, the first collections for almost after 60 years. An updated description of the species based on fresh plant material collected from the type locality (Khasi Hills, Meghalaya, India), along with colour photographs (Fig. 1), are hereby provided for easy identification. A lectotype is also designated for the name as no holotype was cited in the protologue. Table 1 includes selected morphological characters of Impatiens benthamii along with those of similar species.

\section{Taxonomic treatment}

Impatiens benthamii Steenis, Bull. Jard. Bot. Buitenzorg, ser. 3, 17: 385 (1948). Impatiens radicans Benth. ex Hook.f. \& Thomson, J. Proc. Linn. Soc., Bot. 4: 126 (1859), nom. illeg. non Zoll. \& Moritzi (1846); Hooker, Fl. Brit. India 1: 451 (1875); Hooker, Rec. Bot. Surv. India. 4: 33 (1905); Vivekananthan et al., Fl. India 4: 124 (1997). - TYPE: Sillet [Khasi Hills], June 1823, De Silva 1257 [EIC 4763A] (lectotype K [K001039844], designated here). (Fig. 1).

Impatiens salicifolia Hook.f. \& Thomson, J. Proc. Linn. Soc., Bot. 4: 124 (1859), nom. illeg. non Turcz. (1859). - TYPE: Not traced (see notes below).

Perennial herbs, sparsely branched, up to $80 \mathrm{~cm}$ tall; stem quadrangular, hairy, reddish in colour, nodes swollen, light green. Leaves opposite, decussate, distributed evenly along the stem, sessile; petiole to $1 \mathrm{~mm}$ long, pubescent; extrafloral nectaries two, with gland-tipped setae, to $1.5 \mathrm{~mm}$ long; leaf blade lanceolate to narrowly ovate, 
Table 1. Morphological differences between Impatiens benthamii and closely allied species.

\begin{tabular}{lllll}
\hline & $\begin{array}{l}\text { Impatiens } \\
\text { benthamii }\end{array}$ & $\begin{array}{l}\text { Impatiens } \\
\text { trilobata }\end{array}$ & $\begin{array}{l}\text { Impatiens } \\
\text { tripetala }\end{array}$ & $\begin{array}{l}\text { Impatiens } \\
\text { cothurnoides }\end{array}$ \\
\hline Plants & Perennial & Annual & Annual & Perennial \\
Leaves & $\begin{array}{l}\text { Opposite } \\
\text { decussate, } \\
\text { sessile, lanceolate } \\
\text { to narrowly ovate }\end{array}$ & $\begin{array}{l}\text { Opposite } \\
\text { decussate, } \\
\text { petiolate, ovate to }\end{array}$ & $\begin{array}{l}\text { Whorled, } \\
\text { petiolate, ovate }\end{array}$ & $\begin{array}{l}\text { Whorled, linear- } \\
\text { lanceolate }\end{array}$ \\
Flowncle & $0.5-2.5 \mathrm{~cm}$, hairy & $\begin{array}{l}1.5-5.5 \mathrm{~cm}, \\
\text { glabrous }\end{array}$ & $\begin{array}{l}0.2-1 \mathrm{~cm}, \\
\text { glabrous }\end{array}$ & $0.3-1.5 \mathrm{~cm}$, hairy \\
\hline
\end{tabular}

$1-2.7 \times 5-11 \mathrm{~cm}$, base slightly cordate, obtuse to attenuate, apex acute to acuminate, margin shallowly serrate, setose on tip of the teeth, adaxially pubescent, abaxially puberulent along the veins; lateral veins 6-11 pairs, opposite to sub-opposite. Inflorescence axillary; peduncle $0.5-2.5 \mathrm{~cm}$ long, pubescent, yellowish pink, bearing 2 flowers; bract at the base of the pedicel, linear, to $3 \mathrm{~mm}$ long, light green; pedicel 2-4 cm long, pubescent, pink. Flower bud pink with yellowish spur tip, pubescent. Lateral sepals 2, lanceolate, falcate, 0.8-1.5 × 4-5 mm, light greenish mauve, glabrous. Lower sepal bucciniform, abruptly constricted to spur, 1.5-2.1 cm deep, pubescent, mouth funnel-shaped, 1-1.8 cm wide, pink, ventrally pale pink, beaked, beak c. $1 \mathrm{~mm}$ long; spur hooked, 5-10 mm long, tip unifid. Dorsal petal orbicular, 0.9-1.4 cm across, apex emarginate, shortly beaked, both sides mauve, whitish at base on ventral side. Lateral united petals bilobed, subequal, 2-2.5 cm long (whole), glabrous; basal lobe obovate, $0.6-1 \times 0.8-1.3 \mathrm{~cm}$, mauve, apex obtuse, clawed; distal lobe dolabriform, oblong, $0.7-1 \times 1.2-1.6 \mathrm{~cm}$, mauve, apex obtuse; dorsal auricle distinct, to $3 \mathrm{~mm}$ across, yellowish in colour. Stamens $5,0.6-0.9 \mathrm{~cm}$ long, enclosing the ovary, anther lobes obtuse. Capsule green, ovoid, turgid slightly below middle, ridged, glabrous, to $2 \times 1 \mathrm{~cm}$. Seeds ovoid, to $2 \mathrm{~mm}$ across, rusty brown when mature.

Distribution. Endemic to Meghalaya (Khasi Hills, Cherrapunji, Upper Shillong, Laithkar (Laitkor), Mowphlang (Mawphlang), Jaintia Hills, Jawai (Jowai) and adjoining areas).

Phenology. Flowering and fruiting from July to October.

Habitat. Impatiens benthamii grows in moist habitats in open places or at the forest margins of mixed pine forest and on moist road sides from 1000-1430 m. 


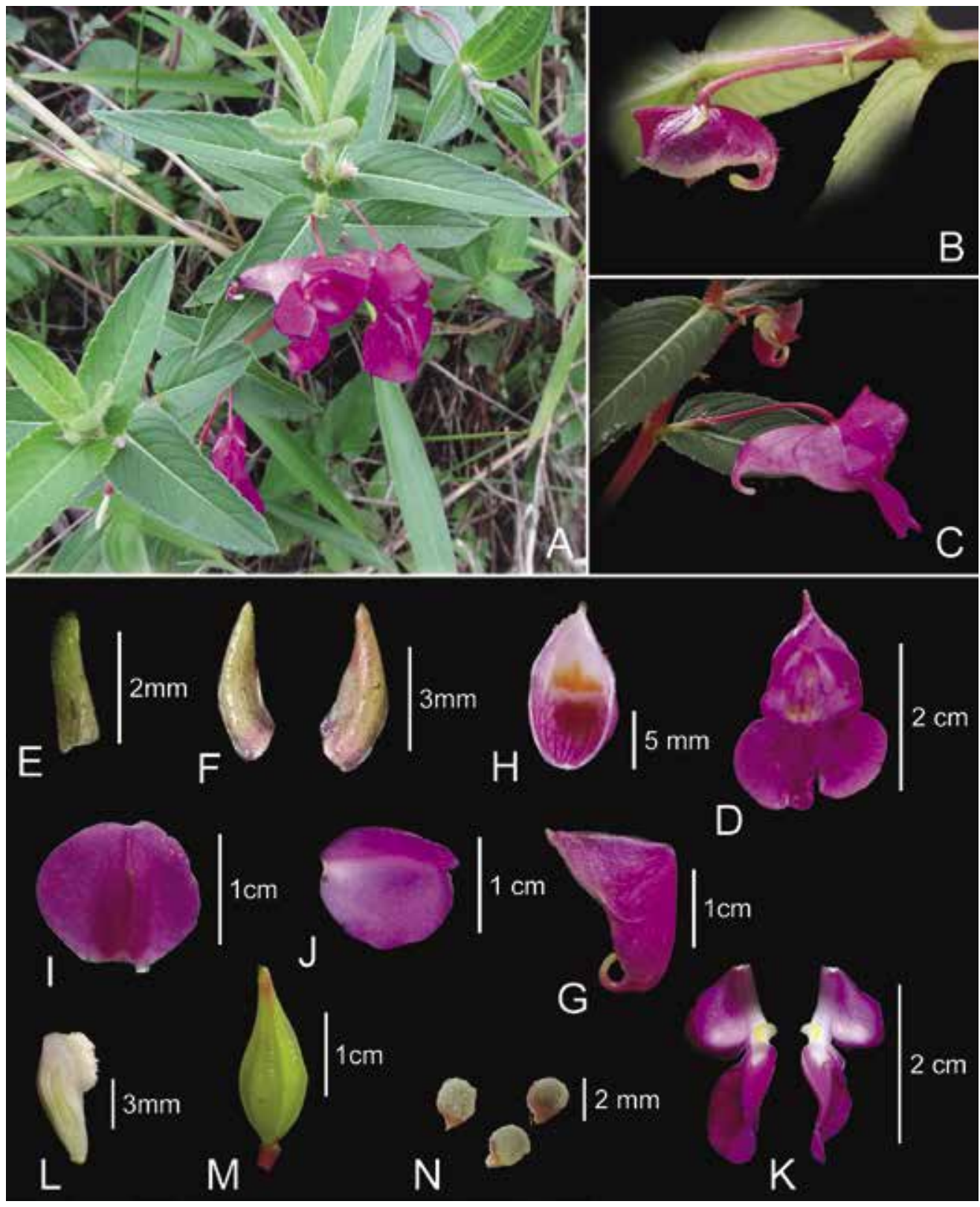

Fig. 1. Impatiens benthamii Steenis. A. Plant in its habitat. B. Flowering twig showing a flower bud. C. Flower (lateral view). D. Front view of flower. E. Bract. F. Lateral sepals. G. Lower sepal. H. Lower sepal (inside with pink venation). I. Dorsal petal (adaxial view). J. Dorsal petal (abaxial view). K. Lateral united petals. L. Androecium (stamens). M. Capsule. N. Seeds. (Photos: A, B.B.T. Tham; B-N, S. Borah). 
Specimens examined. INDIA: Meghalaya: East Khasi Hills, David Scott trail, Sohrarim, $25^{\circ} 16^{\prime} 27^{\prime \prime} \mathrm{N}, 91^{\circ} 43^{\prime} 54^{\prime \prime} \mathrm{E}, 1330 \mathrm{~m}, 16$ Oct 2019, Tham 113435 (ASSAM); East Khasi Hills, Laitkar Forest, 28 Jun 1963, Kar 18076 (ASSAM); East Khasi Hills, Mowphlang, 6000 feet, 20 Aug 1952, Rup Chand Thakur 6420, (MICH [MICH1506330, MICH1506331, MICH1506332]); ibidem, 2 Sep 1952, Koelz 11844 (US [US03363026]); East Khasi Hills, Shillong, 25 Nov 1950, Deka 23039 (ASSAM); Khasi Hills, 28 Jul 1949, Kingdon-Ward 18687 (NY [NY04044556]); ibidem, 1827, Gomez s.n. [EIC 4763A] (CAL [CAL0000065938], K [K001039843]); ibidem, 5000-6000 feet, Jul 1876, Mann 439 (ASSAM); ibidem, Sep 1885, Mann s.n. (ASSAM); Khasya Hills, Griffith s.n. (L [L2325962], P [P04542845]); Khasi Hills, Hooker \& Thomson 21 (BR [BR0000013346713], E [E00837447], MPU [MPU018995], NY [NY04044555] except the middle specimen, P [P04542847, P04542848, P04542849]); Unknown locality and collector 926 (CAL [Acc. no 69858]); Khasiya, Simons 4 (CAL [CAL0000005224, CAL0000005225]); Cherrapunji, 1425 m, 25 Aug 2019, Borah \& Dihingia 0031 (GUBH [GUBH18681]); Jaintia Hills, Jowai, 10 Jun 1911, Burkill \& Banerjee 241 (CAL); Jowai, 6 Oct 1902, Unknown 17736 (E [E00837449]); Jawai, 5000 feet, Sep 1892, King's collector s.n. (E [E00837448]).

Notes. Although the species is little known, during this study it was found that it grows in healthy populations with no obvious threats.

While validly publishing Impatiens radicans Benth. ex Hook.f. \& Thomson (on which the current name I. benthamii is based), Hooker \& Thomson (1859) mentioned that the description of the species is based on collections from the East India Company Herbarium, often cited as Wallich 4763 (but collections actually by F. De Silva and W. Gomez), and collections by Mack, Griffith and others without citing a specific type specimen. No Mack specimen could be traced in any herbarium but the specimen De Silva 1257, also under the EIC number 4763A, collected from the Khasi Hills (labelled as Sillet), is extant in K-W [K001039844]; specimens under Gomez s.n., also under the EIC number 4763A, are extant in CAL [CAL0000065938] and K-W [K001039843]; Griffith s.n. in L [L2325962] and P [P04542845]; Hooker \& Thomson 21 in BR [BR0000013346713], E [E00837447], MPU [MPU018995] and P [P04542847, P04542848, P04542849]. Note that De Silva \& Gomez s.n. [EIC 4763B] (K-W) is the different species Impatiens trilobata Colebr. De Silva 1257 [EIC 4763A] (K-W [K001039844]) has two mature flowering twigs, the name Impatiens radicans Bentham along with J.D. Hooker's initials on the right corner of the sheet, and an original label which mentions the collection number, exact collection month and year on the right side of the sheet. This specimen is designated here as the lectotype.

Hooker \& Thomson (1859) described Impatiens salicifolia on the basis of collections from the Khasi Hills by Lobb and other collectors but during this study no specimens could be traced in any herbarium. We include it in synonymy as Hooker did so himself (Hooker, 1905).

ACKNOWLEDGEMENTS. The authors thank Dr A.A. Mao, Director, Botanical Survey of India, Kolkata for support, logistics and encouragement; Dr Subir Bandyopadhyay, Botanical Survey of India, Kolkata and Dr Wojciech Adamowski University of Warsaw, Poland, for their constant help during the study. The authors also thank Dr Avishek Bhattacharjee, Dr Gopal Krishna, Mr Ashutosh Kumar Upadhyay of CNH, Kolkata, Dr Dilip Roy, BSI, ERC, Shillong 
for providing necessary images for the study. The authors also duly acknowledge the support rendered by the Forests \& Environment Department, Government of Meghalaya for field exploration and Prof. N. Devi, Head, Department of Botany, Gauhati University, Assam.

\section{References}

Clarke, C.B. (1913). Notes on the Khasia localities of Wallich's List. Bull. Misc. Inform. Kew 7: 255-262.

Gogoi, R., Borah, S., Dash, S.S. \& Singh, P. (2018). Balsams of Eastern Himalaya - A Regional Revision. Kolkata: Botanical Survey of India.

Hooker, J.D. (1875). Impatiens L. In: Hooker, J.D. (ed.) The Flora of British India, vol. 1, pp. 440-483. London: L. Reeve \& Co.

Hooker, J.D. (1905). An epitome of the British Indian species of Impatiens. Rec. Bot. Surv. India. 4(2): 11-35.

Hooker, J.D. \& Thomson, T. (1859). Praecursores ad Floram Indicam - Balsaminaceae. J. Proc. Linn. Soc., Bot. 4: 106-146.

Moritzi, A. (1846). Systematisches Verzeichniss der von H. Zollinger in den Jahren $1842-$ 1844 auf Java gesammelten Pflanzen. Solothurn: Im Verlag des Verfassers.

Mostaph, M.K. \& Uddin, S.B. (2013). Dictionary of Plant Names of Bangladesh, Vascular Plants. Chittagong: Janokalyan Prokashani.

POWO (2019). Plants of the World Online. Facilitated by the Royal Botanic Gardens, Kew. Published on the Internet; http://www.plantsoftheworldonline.org/. Accessed 2 Aug. 2020.

Sarmah, K.K. \& Borthakur, S.K. (2009). A checklist of angiospermic plants of Manas National Park in Assam, India. Pleione 3: 190-200.

Turczaninow, N. (1859). Animadversiones ad Secundam partem catalogi plantarum herbaria Universitatis Charkowiensis. Bull. Soc. Imp. Naturalistes Moscou 32(1): 271.

Van Steenis, C.G.G.J.V. (1948). The species of Impatiens indigenous to Java (Bals.). Bull. Jard. Bot. Buitenzorg 17(3): 383-387.

Vivekananthan, K., Rathakrishnan, N.C., Swaminathan, M.S. \& Ghara, L.K. (1997). Balsaminaceae. In: Hajra, P.K. et al. (eds) Flora of India, vol. 4, pp. 95-229. Kolkata: Botanical Survey of India.

Wallich, N. (1832). A Numerical List of Dried Specimens of Plants in the East India Company's Museum: Collected under the Superintendence of Dr. Wallich of the Company's Botanic Garden at Calcutta. London.

Watson, M. (2013). Wallich Catalogue: Sylhet, Pundua \& Khasia Hills. Botanics Stories, RBGE Personal \& Project Stories. https://stories.rbge.org.uk/archives/5029. Accessed 31 Jul. 2020. 